論 文

\title{
遷移金属塩化物担持触媒上でのテトラヒドロフランと アンモニアからのピロリジン生成反応*
}

\author{
野村正勝**, 友金照久**,吉川彰一** \\ Exchange Reaction of Tetrahydrofuran to Pyrrolidine with $\mathrm{NH}_{3}$ over \\ Supported Transition Metal Chloride Catalysts*
}

by Masakatsu Nomura**, Teruhisa Tomogane** and Shöichi Kikkawa**

\begin{abstract}
Summary : The exchange reaction of $\mathrm{THF}$ to pyrrolidine (with $\mathrm{NH}_{3}$ ) was studied using the $\mathrm{LiCl}-\mathrm{KCl}$ supported catalyst containing transition metal chloride $\left(\mathrm{MnCl}_{2}, \mathrm{CoCl}_{2}\right.$ and $\left.\mathrm{NiCl}_{2}\right)$. The excellent selectivities to produce pyrrolidine were observed over $\mathrm{MnCl}_{2}-\mathrm{LiCl}-\mathrm{KCl}$ and $\mathrm{CoCl}_{2}-\mathrm{LiCl}-\mathrm{KCl}$ supported catalysts. The primary by-products were confirmed to be 1-pyrrolidino-2-butene and 4-pyrrolidino-1-butene which are believed to be produced by means of the competitive attack of pyrrolidine (together with the attack of $\mathrm{NH}_{3}$, yielding the expected pyrrolidine) toward an intermediate or protonated THF to yield $\mathrm{N}+\mathrm{HCH}_{2} \mathrm{CH}_{2} \mathrm{CH}_{2} \mathrm{CH}_{2} \mathrm{OH}$ followed by the subsequent dehydration. When the conversion ( $\not 6)$ and selectivity $(\not 6)$ were plotted as a function of wt $\%$ loadings of metal chlorides on a support, it was found that higher loadings (more than $10 \mathrm{wt} \%$ ) markedly suppressed the conversion of THF compared with that over alumina catalyst alone. This indicates that the exchange reaction using higher loadings of support proceeds via a different mechanism from that over alumina alone. This finding and the adsorption experiment of $\mathrm{NH}_{3}$ on catalysts suggest that this exchange reaction over supported catalysts saturated with loadings proceeds through the formation of an ammine complex of transition metal chlorides $\left(\mathrm{CoCl}_{2}, \mathrm{MnCl}_{2}\right)$ with $\mathrm{NH}_{3}$ as an intermediate and the superior selectivity attained by means of these catalysts was also rationalized based on the above proposed mechanism.
\end{abstract}

\section{1 緒 言}

テトラヒドロフランとアンモニアの蒸気をアルミナのような 酸触媒上を通過させることによりピロリジンが容易に得られる

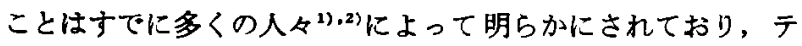
トラヒドロフランから一段階でピロリジンを得る簡便な合成方 法として注視されている。

最近慶(止ら ${ }^{3) ~-5) ~} \mathrm{HL}$ や HY 型ゼオライトを触媒として使 用することにより，転化率 53\%，最高選択率 $91 \%$ でピロリジ ンが得られることを報告している。

著者らは $50 \mathrm{wt} \not 6 \mathrm{LiCl}-50 \mathrm{wt} \% 6 \mathrm{KCl}$ (融点約 $350^{\circ} \mathrm{C}$ ) の 2 元系のアルカリ金属塩化物に僄移金属塩化物を添加した担持触 媒()をテトラヒドロフランとアンモニアによるピロリジン生成 反応に使用したところ, 反応の選択率が最高 $98 \%$ まで改良さ れることを見い出した。

這移金属塩化物を担持した触媒はアルミナだけの場合に比べ て転化率がかなり低下したので，この反応ではアルミナのよう な酸触媒上とは異なった反応機䅹で進むことが推測された。そ こでます副反応抑制の作用機構を検討するため副反応生成物の

$*$ 昭和 51 年 11 月 29 日受理

**大阪大学工学部応用化学教宝 (565 吹田市山田上) Department of Applied Chemistry, Faculty of Engineering Osaka University (Yamadakami, Suita, Osaka 565)
構造を明らかにした。 さらに担持触媒量の変化が転化率や選択率にどのような影響 を及ぼすかを検討し，また触媒の酸性質を知るためアンモニア の吸着を検討し，これらの結果から遷移金属塩化物担持触媒上 ではテトラヒドロフランからピロリジンへの環転換反応が途中 一種のアンミン錯体を形成して経過するのではないかと推定し た。酸点および細孔径分布の異なる 2 種のアルミナを担体とし て使用し，いわゆる担体勃果について若千の検討を行ったので 以下に報告する。

\section{2 実験}

本実験で用いたアルミナは半井化学より入手した触媒用活性 アルミナ [粒径 : $2 \mathrm{~mm} \sim 4 \mathrm{~mm}$, 表面積 : $327 \mathrm{~m}^{2} / \mathrm{g}$ ，最大細孔 径: $1,100 \AA$, 最少細孔径浽 $60 \AA$ 以下と考えられる]と水沢 化学製のネオビード C.4 [粒径 : $2 \mathrm{~mm} \sim 4 \mathrm{~mm}$, 表面積 : 161 $\mathrm{m}^{2} / \mathrm{g}$, 細孔径分布 : $58 \AA \sim 104 \AA$ 趴注 1), 比較的細孔径分布が均 一である]の 2 種である。塩化コバルトは Merck 社製の特級 品を，塩化マンガン，塩化ニッケルは和光純薬製の特級品を使 用した。触媒は浸せき法によりそれぞれのアルミナに担持した。 反応は外径 $20 \mathrm{~mm}$ ，長さ $30 \mathrm{~cm}$ のパイレックス製反応管を具

脚注 1) 細孔经分布は島津製、イクロメリティックスボロシメーター 900 で測定されたもので，この值は担持触媒（10 wt\% 担持） についてもほとんどかわらないことがわかった。 
備した常圧流通反応装置を用いて行った。

反応に先立ち $10 \mathrm{~g}$ の触媒を反応管中窒素気流下で $400^{\circ} \mathrm{C}$ に て 3 時間焼成し, その後 $340^{\circ} \mathrm{C}$ 付近に保ち約 30 分間アンモ二 ア気流中にさらした。テトラヒドロフランとアンモニアの供給 を開始してから 1 時間ごとに液状生成物およびガス状生成物を

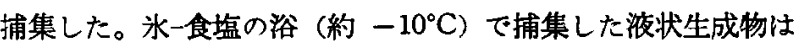
ひょう量後ガスクロマトグラフ法で分析した。またガス状生成 物もガスクロマトグラフ法から組成分析した。以下に述べる結 果は反応開始後 3 時間目のもので, 通常反応開始後 2 時間目か ら反応はほぼ定常状態に入っている。生成物の構造確認はガス クロマトグラフにより分取した成分の NMR スペクトル（日 本電子製高分解能核磁気共鳴装置 JNM-PS-100 型) から，ま た GC-MS (日立製作所製 RMU-6 MG 型) により測定した 未知成分のマススペクトルと別途合成した標品のマススペクト ルの一致およびガスクロマトグラム上での保持時間の一致など から行った。なお ESR スペクトルの測定は日本電子製高分解 能電子スピン共鳴装置 (JES-ME-2X 型) を使用した。触媒 の表面積は BET 窒素吸着法により測定した。またアンモニア の吸着測定は原らりによって記載されたものと類似の吸収管を 使用し行った。

\section{3 結果と考察}

\section{1 二つの異なるアルミナ担体を用いた担持触媒による}

環転換反応について

細孔径分布の不均一な 高表面積の活性アルミナ に $\mathrm{CoCl}_{2}$ (5) $-\mathrm{LiCl}(2.5)$ $-\mathrm{KCl}(2.5), \mathrm{MnCl}_{2}(5)$ $-\mathrm{LiCl}(2.5)-\mathrm{KCl}-(2.5)$, $\mathrm{NiCl}_{2}(5)-\mathrm{LiCl}(2.5) \mathrm{KCl}$ (2.5) [( ) 内の値は担持 触媒中に占める担持金属 塩化物の $\mathrm{wt} \not 6$ を示す] の 3 種の 3 元采塩をそれ ぞれ担持した触媒を用い て環転換反応を行った。

反応に際しテトラヒドロフ ランおよびアンモニアの蒸気 をアルゴン等で希积すると選 択率や転化率が低下したので 希釈せナ゙に反応を行った。ま た最適反応温度を決めるため に $300^{\circ} \mathrm{C}, 340^{\circ} \mathrm{C}$ および 390 ${ }^{\circ} \mathrm{C}$ で反応を行ったところ， ピロリジンの転化率や選択率 が $340^{\circ} \mathrm{C}$ で最も高いことがわ かったので，以下この温度で 反応を行った。反応結果を表 1 に示す。

生成物はピロリジンのほか 主たる副反応生成物は $1-ヒ ゚$ ロリジノー2-ブテンと 4-ピロ
後者は Reppe らの總説》においてその生成が指摘されており， 本研究ではガスクロマトグラフより分離した留分のピクレート の融点 $\left(105^{\circ} \mathrm{C}\right)$ が 4-クロロ-1-ブテンとピロリジンより合成し た標品のピクレートの融点と一致したこと，およびマススペク トルも標品のものと一致したことから確認した。1ーピロリジ ノー2-ブテンの生成は標品のマススペクトルと GC-MS から得 た留分のマススペクトルが完全に一致したことから確認した。

アルミナだけの場合は 79\% と高い転化率を示すのに対し， 遷移金属塩化物を担持した場合はすべて転化率の值が低下して いるのが特徴的で, $\mathrm{NiCl}_{2}-\mathrm{LiCl}-\mathrm{KCl}$ を担持した場合には全く 反応が起こらなかった。しかしながら選択率は $\mathrm{CoCl}_{2}$ 系で少 し上昇しており， $\mathrm{MnCl}_{2}$ 系ではアルミナだけの場合に比べて 約 $10 \%$ の上昇がみられた。またアルミナだけの場合は副生物 の 1-ピロリジノ-2-ブテンが 4-ピロリジノ-1-プテンより多く 生成しているのに対し，担持触媒では前者がほとんど生成せず 後者が優位に生成しているのが特衟的と言える。

安井ら”は，触媒反応に及ぼす担体の作用として均一な細孔 径分布の重要性を指摘しているが，本反応で用いた最初のアル ミナは細孔径が $60 \AA$ 以下のものから $1,100 \AA$ のものまで広 範囲にわたっており，また酸点も比較的弱いため(アミン滴定 に上り求めた $p K_{a} 0.8$ 3.3 の酸点量沬ほとんど零であった), 均一な細孔径分布をもつ比較的酸点の強いアルミナとして水沢 化学製ネオビード C.4 を用い，環転換反応を行った。このよ

\begin{tabular}{|c|c|c|c|c|c|c|c|c|}
\hline \multirow[b]{2}{*}{ Supported Metal Chlorides } & \multirow[b]{2}{*}{$\begin{array}{c}\mathrm{SA} \\
\left(\mathrm{m}^{2} / \mathrm{g}\right)\end{array}$} & \multicolumn{5}{|c|}{ \%6 Yields of Products b) } & \multirow[b]{2}{*}{$\begin{array}{l}\text { Conv. } \\
(\mathscr{6})\end{array}$} & \multirow[b]{2}{*}{$\begin{array}{c}\text { Selectivity } \\
\text { (\%) }\end{array}$} \\
\hline & & $\stackrel{\mathrm{N}}{\mathrm{H}}$ & $\begin{array}{l}\mathrm{N}^{3} \mathrm{C}= \\
\stackrel{1}{\mathrm{C}}-\stackrel{1}{\mathrm{C}}\end{array}$ & $\underset{\mathrm{C}}{\mathrm{N}}-\stackrel{\mathrm{I}}{\mathrm{C}} \mathrm{C}-\mathrm{C}$ & $\mathrm{C}_{3}^{-}$ & $\mathrm{C}_{4}=$ & & \\
\hline $\mathrm{CoCl}_{2}(5.0)-\mathrm{LiCl}(2.5)-\mathrm{KCl}(2.5)$ & 294 & 41 & 6.2 & tr & 0.9 & 0.8 & 60 & 68 \\
\hline $\mathrm{MnCl}_{2}(5.0)-\mathrm{LiCl}(2.5)-\mathrm{KCl}(2.5)$ & 264 & 29 & 5.1 & $\operatorname{tr}$ & 0.3 & 0.3 & 39 & 74 \\
\hline $\mathrm{NiCl}_{2}(5.0)-\mathrm{LiCl}(2.5)-\mathrm{KCl}(2.5)$ & 244 & - & - & no reaction & - & - & - & - \\
\hline- & 324 & 51 & 8.0 & 11 & 0.7 & 7.5 & 79 & 64 \\
\hline
\end{tabular}

a) Reaction conditions : Catalyst : $10.0 \mathrm{~g} . \mathrm{THF}: 0.0215 \mathrm{~mol} / \mathrm{hr}, \mathrm{NH}_{3}: 0.086 \mathrm{~mol} / \mathrm{hr}$.

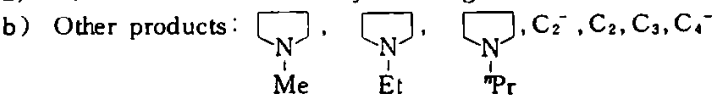

Table 2 Effect of Transition Metal Additives on the Exchange Reaction $\left(340^{\circ} \mathrm{C}\right)$

\begin{tabular}{|c|c|c|c|c|c|c|c|}
\hline \multirow[b]{2}{*}{$\begin{array}{l}\text { Supported Metal } \\
\text { Chlorides }\end{array}$} & \multicolumn{5}{|c|}{ \%6 Yield of Products } & \multirow[b]{2}{*}{$\begin{array}{l}\text { Conv. } \\
\text { (क) }\end{array}$} & \multirow[b]{2}{*}{$\begin{array}{c}\text { Selectivity } \\
\text { (क्) }\end{array}$} \\
\hline & $\begin{array}{l}\mathrm{N} \\
\mathrm{H}\end{array}$ & $\begin{array}{l}N^{\prime} \mathrm{C}=\mathrm{C} \\
\stackrel{\mathrm{I}}{\mathrm{C}}-\stackrel{\mathrm{C}}{\mathrm{C}}\end{array}$ & $\stackrel{C}{C}-\stackrel{1}{C}$ & $\mathrm{C}_{3}{ }^{-}$ & $C_{4}=$ & & \\
\hline $\mathrm{CoCl}_{2}(5.0)$ & 72 & 7.2 & - & 1.5 & 0.4 & 85 & 85 \\
\hline $\mathrm{CoCl}_{2}(2.0)-\mathrm{LiCl}(1.0)-\mathrm{KCl}(1.0)$ & 68 & 7.8 & - & 1.6 & 1.5 & 80 & 85 \\
\hline $\mathrm{CoCl}_{2}(3.5)-\mathrm{LiCl}(1.75)-\mathrm{KCl}(1.75)$ & 70 & 5.5 & - & 1.7 & tr & 78 & 89 \\
\hline $\mathrm{CoCl}_{2}(5.0)-\mathrm{LiCl}(2.5)-\mathrm{KCl}(2.5)^{\mathrm{a}}$ & 34 & 0.4 & - & 0.8 & tr & 36 & 95 \\
\hline $\mathrm{CoCl}_{2}(8.0)-\mathrm{LiCl}(4.0)-\mathrm{KCl}(4.0)$ & 33 & $\operatorname{tr}$ & - & $\operatorname{tr}$ & - & 35 & 95 \\
\hline $\mathrm{MnCl}_{2}(5.0)$ & 79 & 6.4 & - & 2.1 & 2.2 & 90 & 88 \\
\hline $\mathrm{MnCl}_{2}(2.0)-\mathrm{LiCl}(1.0)-\mathrm{KCl}(1.0)$ & 74 & 7.8 & $\operatorname{tr}$ & 2.0 & 2.7 & 87 & 85 \\
\hline $\mathrm{MnCl}_{2}(3.5)-\mathrm{LiCl}(1.75)-\mathrm{KCl}(1.75)$ & 76 & 5.6 & tr & 1.8 & - & 84 & 90 \\
\hline $\mathrm{MnCl}_{2}(5.0)-\mathrm{LiCl}(2.5)-\mathrm{KCl}(2.5)^{\mathrm{bl}}$ & 60 & 2.5 & - & 1.0 & - & 64 & 94 \\
\hline $\mathrm{MnCl}_{2}(8.0)-\mathrm{LiCl}(4.0)-\mathrm{KCl}(4.0)$ & 53 & 1.0 & - & tr & - & 54 & 98 \\
\hline $\mathrm{NiCl}_{2}(5.0)$ & 45 & 3.0 & tr & 2.4 & - & 85 & 53 \\
\hline $\mathrm{NiCl}_{2}(2.0)-\mathrm{LiCl}(1.0)-\mathrm{KCl}(1.0)$ & 59 & 5.5 & - & 1.5 & tr & 67 & 88 \\
\hline $\left.\mathrm{NiCl}_{2}(5.0)-\mathrm{LiCl}(2.5)-\mathrm{KCl}(2.5)^{\mathrm{c}}\right)$ & - & - & no reaction & - & - & - & - \\
\hline$-d$ & 72 & 8.7 & 2.7 & 1.6 & 4.5 & 94 & 77 \\
\hline
\end{tabular}

a) $\mathrm{SA}: 136 \mathrm{~m}^{2} / \mathrm{g}$, b) $\mathrm{SA}: 124 \mathrm{~m}^{2} / \mathrm{g}$, c) $\mathrm{SA}: 126 \mathrm{~m}^{2} / \mathrm{g}$, d) $\mathrm{SA}: 161 \mathrm{~m}^{2} / \mathrm{g}$. 
リジノ-1-ブテンであった。

うな担体を用いたのは一つには本触媒の焼成温度 $400^{\circ} \mathrm{C}$ では 担持塩化物が溶融した状態にあると思われるので,これらの塩 の均一な分散を図るためでもある。反応結果を表 2 に示す。

表 1 の場合と同様に担持触媒ではアルミナだけの場合に比べ ると枟化率は低くなっているが，逥択率は $\mathrm{NiCl}_{2}(5)$ および $\mathrm{NiCl}_{2}(5)-\mathrm{LiCl}(2.5)-\mathrm{KCl}(2.5)$ の場合を除いてすへて改良さ れている。 $\mathrm{MnCl}_{2}(8)-\mathrm{LiCl}(4)-\mathrm{KCl}(4)$ の場合,転化率 $54 \%$ で 選択率は最高值 98\% を示才。 $\mathrm{CoCl}_{2}(5)-\mathrm{LiCl}(2.5)-\mathrm{KCl}(2.5)$ の場合と $\mathrm{MnCl}_{2}(5)-\mathrm{LiCl}(2.5)-\mathrm{KCl}(2.5)$ の場合は選択率は 95\% 程度で, 対応する転化率は 36\% および $64 \%$ となってい る。これに対し $\mathrm{CoCl}_{2}(3.5)-\mathrm{LiCl}(1.75)-\mathrm{KCl}(1.75)$ と $\mathrm{Mn}$. $\mathrm{Cl}_{2}$ (3.5)- $\mathrm{LiCl}(1.75)-\mathrm{KCl}(1.75)$ では共に選択率 90\% 近くで 転化率はそれぞれ 78\% および 84\% と高くなっている。

またアルミナだけの場合注１の場合に比べる上転化率む選 択率も共に上㫒している。またこの場合副生物は 4-ピロリジ ノー1-ブテンが多く1-ピロリジノー2-ブテンの生成は少ない。

次に本反态の転化率, 選択率, 収率に対する 3 元系塩の担持 量の影響を調べるために表 2 の $\mathrm{MnCl}_{2}$ 采および $\mathrm{CoCl}_{2}$ 系塩 の結果を図 $1 \mathrm{a})$, b) にプロットした。図より選択率岋担持量 の増加と共に単調に増加することが明らかであるが，ここで興 味のあるのは塩の担持量が $7.0 \mathrm{wt} \%$ (要移金属塩化物は 3.5 wt \%) 加 $10.0 \mathrm{wt} \mathscr{6}$ （要移金属塩化物は $5.0 \mathrm{wt} \mathscr{6}$ ）に増加 すると，両者とも収率と転化率が著しく低下してこの点で断層 を示すことである。この事実塩の担持量が $7.0 \mathrm{wt} \%$ より低 い触媒では本反応が主としてアルミナの表面酸点により触媒作

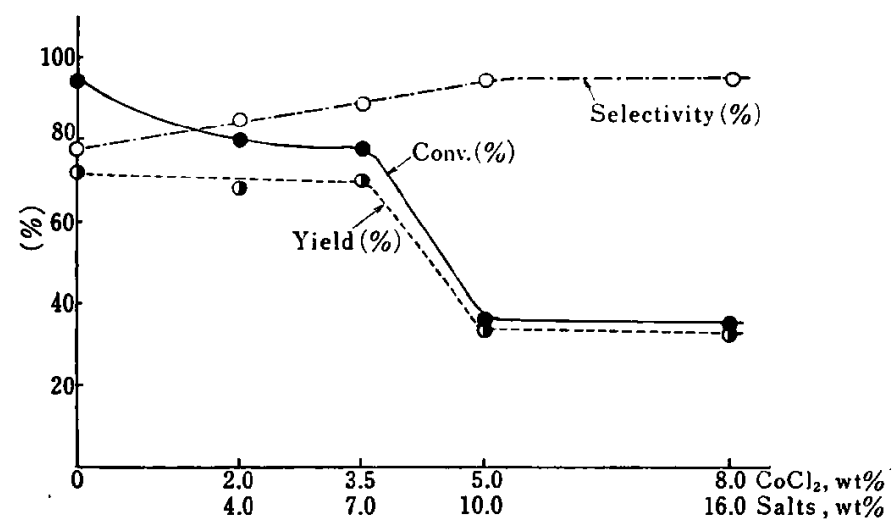

Fig. 1 a) Plots of Conv. (\%), Yield (\%) and Selectivity (\%) against Supported Amounts of $\mathrm{CoCl}_{2}-\mathrm{LiCl}-\mathrm{KCl}$

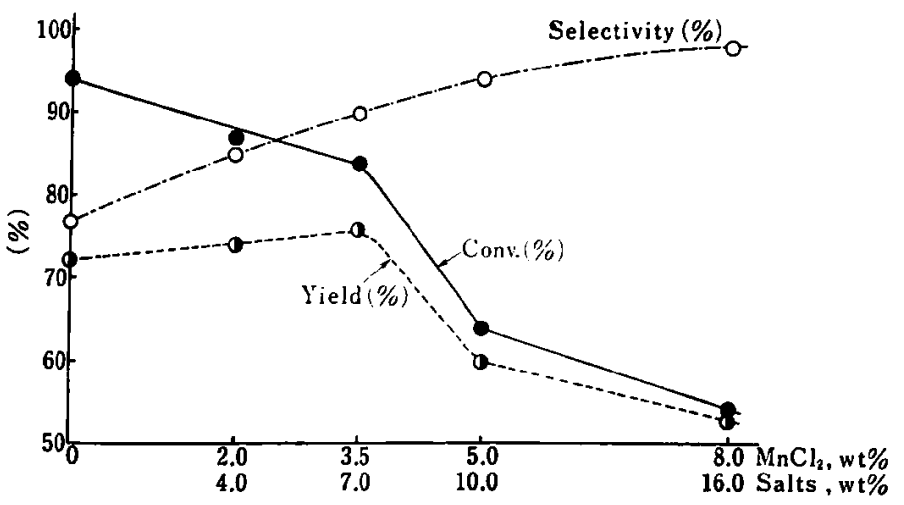

Fig. 1 b) Plots of Conv. (\%), Yield (\%) and Selectivity (\%) against Supported Amounts of $\mathrm{MnCl}_{2}-\mathrm{LiCl}-\mathrm{KCl}$
用を受けるのに対し，塩の担持量が $10 \mathrm{wt} \%$ より高いところ ではアルミナの表面がほほ塩によっておおわれるため，遷移金 属塩化物そのものによる触媒作用によって反応が進行すると考 えられる。

3.2 使用した触媒の性状について

使用した触媒の酸性質を調べるために Rooney らの方法 ${ }^{10)}$ 従ってペリレンの吸着によるカチオンラジカルの ESR スペク トルを測定した。これは触媒上のルイス酸点を評価する一つの 方法であるが，本触媒調製の条件下では表 1，表 2 で使用した アルミナは共にペリレンのカチオンラジカルから推定されるル イス酸の澧度は非常に低く畔注 2)，ほとんどこの酸点の作用を 考える必要のないことがわかった。

Table $3 \mathrm{NH}_{3}$ Absorbed on the Catalysts $\left(25^{\circ} \mathrm{C}\right.$ )

\begin{tabular}{l|c}
\hline \multicolumn{1}{c|}{ Catalysts } & Absorbed $\mathrm{NH}_{3}(\mathrm{~m} \cdot \mathrm{eq} / \mathrm{g})$ \\
\hline Alumina (Neobead $\mathrm{C} \cdot 4)$ & $1.3(1.1)^{\mathrm{a}}$ \\
$\mathrm{CoCl}_{2}(5)-\mathrm{LiCl}(2.5)-\mathrm{KCl}(2.5)$ & 4.3 \\
$\mathrm{MnCl}_{2}(5)-\mathrm{LiCl}(2.5)-\mathrm{KCl}(2.5)$ & 4.6 \\
$\mathrm{NiCl}_{2}(5)-\mathrm{LiCl}(2.5)-\mathrm{KCl}(2.5)$ & 3.4 \\
\hline a) This figure indicates the acid sites (pKa $0.8 \sim 3.3$ ) \\
\multicolumn{2}{|c|}{ estimated by amine titration methods. }
\end{tabular}

そこで指示薬ジメチルイエローを用いて $p K_{a} 0.8 \sim 3.3$ の プレンステッド酸点の定量を行ったが，担持触媒では表面が着 色しているため終点の判定が困難であったので, 酸点の評価の 一手段としてアンモニアの吸着実験を行った。表 3にその結果 を示す。表よりネオビードC.4のアンモニア吸着量はアミン滴 定により求めた $p K_{a} 0.8 \sim 3.3$ の酸点量 $(1.1 \mathrm{~m} \cdot \mathrm{eq} / \mathrm{g})$ に近い ことがわかる。これに対し $10 \mathrm{wt} \%$ の塩を担持した触媒 では表面積がアルミナそのものより幾分低下しているにも かかわらず (表 2 参照) アンモニア吸着量が多い。これは 表面の遷移金属塩化物にアンモニアが配位した結果と推定 される。しかもこの吸着量が $\mathrm{MnCl}_{2}>\mathrm{CoCl}_{2}>\mathrm{NiCl}_{2}$ と なってテトラヒドロフランの環転換反応の反応性の順序に 一致している点が興味梁いところである。

\section{3 ピロリジンへの環転換反応に関する反応過程に} วいて

慶伊ら”は反応速度の測定などからゼオライト上でのテ トラヒドロフランからピロリジンへの環転換反応はブレン ステット゚酸点により触媒作用を受ける反応であり，テトラ ヒドロフランへのプロトン付加からオープンカルボニウム イオン $\mathrm{HO}\left(\mathrm{CH}_{2}\right)_{3} \mathrm{CH}_{2}{ }^{+}$が生成し，これがアンモニアと 反応して $\mathrm{HO}\left(\mathrm{CH}_{2}\right)_{3} \mathrm{CH}_{2} \stackrel{+}{\mathrm{N}} \mathrm{H}_{3}$ が生成するところを律速段 階としている。3.2 でもすでに述べたように，アルミナ上 での本反応はアルミナ表面のブレンステッド酸点により活 性化を受ける反応であると考えられる。本反応過程の中間 にオープンカルボニウムイオンが関与寸るかどうかを調べ るために，2-メチルテトラヒドロフランおよびテトラヒド ロピランの環転換反応を本反応条件と同一の条件下（テト ラヒドロピランの場合は反応温度が $380^{\circ} \mathrm{C}$ である) で行っ た。表 4 にその結果を示す。ネオビードC.4を用いた時は 2-メチルテトラヒドロフランの反応では転化率が $82.4 \%$

脚注 2) ESR スペクトルより求めたネオビードC・4 上でのペリ レンのカチオンラジカルの浱度は! $3.17 \times 10^{18} \mathrm{spins} / \mathrm{g}$ ( $G$ 值 2.0035) であった。 
Table 4 Exchange Reactions Using $\alpha$-Methyl tetrahydrofuran and Tetrahydropyran as Starting Materials

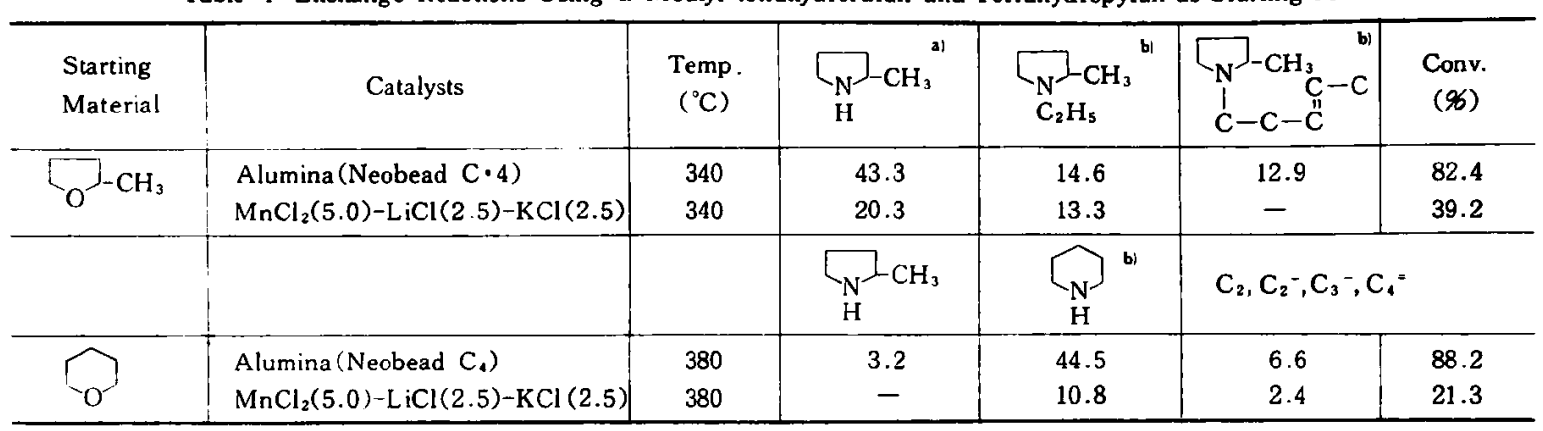

a) Confirmed on the basis of NMR spectrum(in $\mathrm{CDCl}_{3}$ ) of the corresponding fraction separated by a preparative gas chromatography $\left[\delta 1.10\left(3 \mathrm{H}, \mathrm{d}, \mathrm{CH}_{3}\right), 1.70\left(4 \mathrm{H},-\mathrm{CH}_{2} \mathrm{CH}_{2}-\right), 2.08(\mathrm{lH}, \mathrm{s}, \mathrm{NH}), 2.92\left(3 \mathrm{H}, \mathrm{m},-\mathrm{CH}_{2} \mathrm{NHCH}^{-}\right)\right]$

b) Confirmed by means of their mass spectra obtained by $\mathrm{GC}-\mathrm{MS}$ technique

でテトラヒドロフランに比べ低く，この事実はプロトンの酸素 上への攻撃に続く O-C 結合の切断が律速段階でないことを物 語っている。同様のことが担持触媒の場合にも言える。テトラ ヒドロピランを出発物䱜とした時はネオビードC.4 上では 3.2 و6 の 2-メチルピロリジンと 44.5\% のピペリジンが生成した。 もしも反応の途中にオープンカルボニウムイオンが関与するな

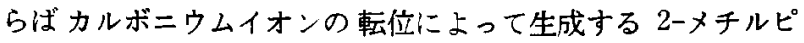
ロリジンが優先的に生成しても不思議ではない。従ってテトラ ヒドロフランヘプロトンが攻撃してできるプロトン化テトラヒ ドロフランの ※位の炭素をアンモニアが攻慗するとともにC$\mathrm{O}$ 結合が開裂して $\mathrm{HO}\left(\mathrm{CH}_{2}\right)_{3} \mathrm{CH}_{2} \stackrel{+}{\mathrm{N}} \mathrm{H}_{3}$ が生成するプロセスが 途中にオープンカルボニウムイオンが関与するプロセスよりも 重要な反応過程ではないかと考えられる。また担持触媒では 2ーメチルピロリジンが全く生成していないのが興味ある事実で ある。ところでテトラヒドロフランの主要な副生物は 1-ピロリ ジノー2-ブテンおよび 4-ピロリジノー1-ブテンの二つであった が，担持触媒では前者はほとんど生成していない。これらの副 生物はプロトン化したテトラヒドロフランを生成したピロリジ ン（アンモニアより強塩基）がアンモニアと競争的に攻撃し中 間体として するかまたは途中カルボニウムイオンの転位を経て生成される ものと考えられる。従ってネオビード C・4 上での環転換反灾 のプロセスとして以下の機構が考えられる。

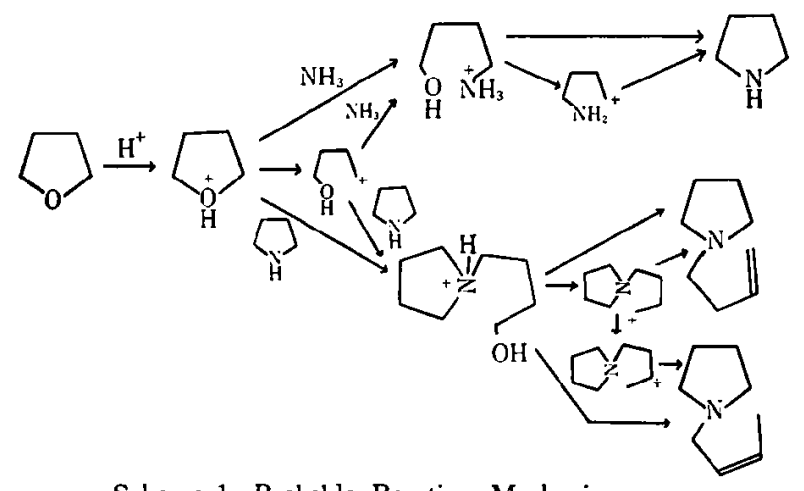

Scheme 1 Probable Reaction Mechanism over Alumina Catalysts

担持触媒では転化率は低下寸るが選択率は最高 98\% まで改 良された。しかもこの場合は担持触媒量が $16 \mathrm{wt} \%$ でフルミ ナ表面を十分㧍おっている状態にあると考えられるので，反応 はアルミナのブレンステッド酸点の作用を受けず遷移金属塩化
物の作用によってのみ進行すると考えることができる。その作 用は恐らくスキーム2に記したごとく金属塩化物に配位したア ンモニアから生成するプロトンによって開始され，プロトン化 したテトラヒドロフランの酸素原子に隣接する炭素はアンミン 錯体中の $\mathrm{NH}_{2}-$ によって求核的攻撃を受け開裂して直接 $\mathrm{HO}$. $\left(\mathrm{CH}_{2}\right)_{4} \mathrm{NH}_{2}$ を与えるであろう。

$$
\begin{aligned}
\mathrm{MeCl}_{2} \stackrel{n \mathrm{NH}_{3}}{\longrightarrow} \text { Ammine complex } \\
\longrightarrow \text { Ammine complex coordinated with } \mathrm{NH}_{2}{ }^{-}+\mathrm{H}^{+}
\end{aligned}
$$

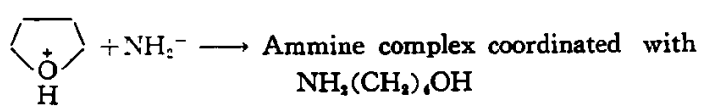

Ammine complex with $\mathrm{NH}_{2}\left(\mathrm{CH}_{2}\right)_{4} \mathrm{OH}$ $\stackrel{\mathrm{NH}_{2}}{\longrightarrow}$ Ammine complex $(\mathrm{I})+\mathrm{NH}_{2}\left(\mathrm{CH}_{2}\right)_{2} \mathrm{OH}$<smiles>C1CCC(C2CCNC2)C1</smiles>

Scheme 2 Probable Reaction Mechanism over Transition Metal Chloride Supported Catalysts

途中のアンミン錯体は必ずしもアンモニアだけが配位してい る必要はなく水なども配位子として考えられよう。ここでピロ リジンより生成する共役塩基はアンモニアの共役塩基に比へ塩 基性が低いことなどのため生成したピロリジンが関与する副反 応が抑えられると考えられる。なお担持量が $4.0 \mathrm{wt} \%, 7.0$ $\mathrm{wt}$ 名などの場合には選択率が落ち転化率が上㫒してくる。こ の場合はアルミナ表面のブレンステッド酸点が反応に関与して くると考えられるから，スキーム1とスキーム 2 の両方の過程 が奇与すると考えられる。

\section{文}

1) Yur'ev, Yu-K, Prokina, M.N., Chem. Abst., 32, 548 (1938)

2) Kawaguchi, T., Kita, T., Naito, H., 日特 6,819,940 (1969).

3) Hatada, K., Shimada, M., Fujita, K., Ono, Y., Keii, T., Chem. Letters, 1974, 439.

4) Fujita, K., Hatada, K., Ono, Y., Keii, T., J. Catalysis, 35, 325 (1974).

5) Ono, Y., Hatada, K., Fujita, K., Halgeri, A., Keii, T., ibid., 41, 322 (1976).

6) Fox, D.B., Lee, E.H., Chem. Tech., 1973, 186.

7）原 伸宜, 池部 清, 三田幸太郎, 工化, 58, 377 (1953).

8) Reppe und Mitarbeiter, Ann. Chem., 596, 102 (1955).

9）安井昭夫, 中村征四郎，触媒，14，(6)，187 (1972).

$10)$ Rooney, J.J., Pink, R.C., Trans. Faraday Soc., 58, 1632 (1962). 